\title{
Feminist Pedagogy in Early Childhood Teachers' Education
}

\author{
Haggith Gor Ziv \\ Correspondence: Haggith Gor Ziv, Kibbutzim College of Education, Early Childhood Department, Gender Studies, Tel \\ Aviv University, Israel
}

Received: August 6, 2015 Accepted: August 20, 2015 Online Published: September 6, 2015

doi:10.11114/jets.v3i6.1072

URL: http://dx.doi.org/10.11114/jets.v3i6.1072

\begin{abstract}
This article discusses the theory and practice of applying critical feminist pedagogy in a teacher's training college. It is based on an analysis of the education of students in an early childhood teaching program (BEd) that seeks to promote social justice through education. This article discusses the areas of the student's education that encourage critical thinking, social critique and questioning of the social order that continues to stratify young children into the social class of their birth. The article explains the principles that guide my work as an educator in an Israeli teacher's college and how I seek to expose students to ideas and concepts like the meaning of a feminine career choice, the potential to transform acquired perceptions, practice in marginalized communities, personal and political narratives and opportunities for resistance.
\end{abstract}

Keywords: critical feminist pedagogy, early childhood, teachers training, social conscious, social justice, gender, class, transformative education

\section{Introduction}

Teacher's education prepares teachers to work in the current educational system. Whilst their training may pay lip service to ideas of equality and equal opportunity, rarely are teachers-in-training given the opportunity to learn practical tools for rectifying inequalities in the classroom or for educating in ways that increase opportunities for all students. Critical feminist pedagogy is concerned with how education creates and entrenches existing structures of power and seeks to provide practical tools for redressing inequality both within the classroom and in society at large. This article analyses my attempts to create a training program for teachers based on the principles of critical feminist pedagogy.

\subsection{Description}

In my work as an educator at Kibbutzim College of Education in the Early Childhood department, I implement the principles of critical feminist pedagogy. Practical and theoretical aspects of implementing critical feminist pedagogy in a early childhood teacher training aren't available in the literature. Therefor an attempt to examine ways to educate students to see teaching as a social mission and an opportunity for the creation of social change might contribute to the general knowledge of teacheres preparation. The paper offers insights into the creation of a practical program for teachers' education in the context of commitment to egalitarian education and social justice. This paper thus contributes to the knowledge of ways to apply critical feminist pedagogy to mobilize students into activism for social change via transformational education.

The article deals with the following questions: how to prepare student-teachers for educational work that will create social transformation? How to educate early childhood teachers to be sensitive to issues of inequality and discrimination? How to make early childhood teachers aware of existing social stratification and the need for educational alternatives?

\subsection{Study Context}

In Israel, the B. Ed. Education and Teacher's Certificate studies takes four years. During the first three years, students attend an intensive program that offers training in general knowledge and teaching practice. In the fourth year, students teach at schools and receive pay while continuing to attend classes one day a week. The program I teach in is part of the Early Childhood department that prepares teachers to work with children from birth to six years old and offers a specialization in Special Education. The students in the program are mostly young women between the ages of $20-25$. Most of the students are single with no children. Jewish students are evenly split between those with Sephardic/Mizrachi backgrounds and those from Ashkenazi backgrounds. There is also a small number of Arab students. Occasionally new immigrants or students with learning disabilities or severe disabilities participate in the program. 


\subsection{What is feminist Critical Pedagogy?}

Critical pedagogy seeks to investigate the ways education creates and enforces class division under capitalism. Feminist critical pedagogy additionally seeks to explore how gender inequality is perpetuated through educational systems and offers liberatory, educational alternatives that endeavor to create social change (Shor and Freire 1990). Feminism offers a lens that allows us to analyze and understand phenomena in the social world through recognizing the hierarchical nature of gender under patriarchy. (Kenway and Modra, 1992). Feminist critical pedagogy therefore seeks to explore how the marginalization and "othering" (De Beauvoir, 2001) of women takes place through specific educational practices, such as gender-biased curricula, hidden and overt messages given to students and the effect of instruction style on boys and girls.

Feminist critical pedagogy seeks to promote equality between different groups in society through education and expose the mechanisms in education that marginalize certain groups. It confronts educational institutions with questions such as: what hidden forces of discrimination continue to act against children from different backgrounds? How can they be transformed? What is the impact of the social structure and power hierarchy in our educational institutions? What kind of hidden messages does our curriculum convey? In what ways do hegemonic forces continue to control the atmosphere in the school and the content of the curriculum? Whose voices are absent from our curricula? Whose interests are served by our educational system and the dominant discourses of education that it reflects?

There are two central orientations in critical pedagogy. The first orientation, demonstrated in the research of Henry Giroux and Peter McLaren, emphasizes a vision of social change reflected in educational practice. The second orientation, which is demonstrated by Ira Shor and Paulo Freire, emphasizes changes to methods of instruction in specific contexts. Similarly, feminist critical pedagogy can be divided into two streams, one that focuses on feminist theory and its application to education and another that focuses specifically on methods of teaching. The first stream emerged from Women's Studies departments while the second emerged in the study of education (Gore, 1992).

\section{Methodology}

\subsection{The Methodological Approach}

Feminist research recognizes the essential role of gender and how it influences our lives. Feminist research methodology asks questions about the relationship between knowledge and power in society, investigates how patriarchal values impact knowledge and processes of research and seeks ways to ameliorate its effects.

This article describes the ways transformative teachers education uses feminist methodology and how it affects students' teachers. The goal of feminist research is to change the invisibility of gender and the distorted place of women in an unequal society. (Lahar, 1988) Amyia Liblich calls for a change in the dominant discourse by exposing women's voices. (Lieblich, 1993) Michelle Fine (1988) argues that a researcher should go beyond using the research to produce a narrative for academic purposes; she insists that it is important to include the participants throughout the process of the study. This way they contribute to the generative meaning making of their transformational purposes. In her work with women prisoners she demonstrates the difficulties inherent in negotiating for meaning dialectically.

My students were raised with ideology of patriarchy and militarism of Israeli society and therefore I constantly wrestle with the question of how to educate such students to be committed to counter-hegemonic praxis and how to engage them in egalitarian discourse and educational practice. Through the article I problematize my ways of instruction using critical feminist theory to generate theoretically based understandings of my students' transformative learning process and components. Feminist research does not create a distinction between the knowledge produced and the research methods that were used. Rather, the research methods, the research participants, the researcher and the research itself are inseparable and integral to the understanding generated by the research.

\subsection{Research Material}

The research data was drawn from analysis of written papers from students, participant observations, observation of group dynamics in class, field observations, observations of student teachers, supervision discussions. Feminist research acknowledges that the analysis of research material is reflective of the worldview of the researcher. (Kohn, 1989) This research makes use of a pragmatic analysis (Dascal, 2003) of the research material. This style of analysis recognizes that above the spoken word is a realm of meanings that are conveyed through the language we use. Pragmatic analysis seeks to go beyond the words that are said to understand what meaning the speaker was intending to convey. The analysis also searches for the way social power, dominance, and inequality are manifested and recreated. It uses means of critical discourse analysis that takes a clear position to resist social inequality.(Van Dijk, T. 2003).This research also addresses the material from the approach of grounded theory, seeking to base the theoretical insights gained directly from the research material and the experience in the field.

\subsection{The Researcher as an Instrument}


Traditional, patriarchal research suggests that it is possible for the researcher to attain a state of objectivity that allows a suitably trained mind to create knowledge independent of their worldview and personal circumstances. Feminist research critiques this notion of objectivity, suggesting instead that the context and worldview of the researcher is a central component of the research data that will be produced. In this context, the researcher herself is one of the research instruments and is central to the research process as well as part of the knowledge that is created. (Merriam, 2002) The researcher is required to engage in a process of 'estrangement' from the research material, seeking not just to view the material from the perspective of the research participants, or from their own perspective, but to dismantle the research into its component parts and reconstruct it in order to create new insights that may have not been immediately apparent.

Feminist research is a reflexive process that requires the researcher to consider her own position, both as a researcher and as a component of the research field, who impacts and changes the conditions present.

\subsection{Computerized Research Instruments: Atlas Data Analysis System}

The research material was analyzed through the Atlas computerized data analysis system. Atlas allows researchers to manipulate qualitative research material, view connections between data, create themes and analyze both the content and structure of qualitative data in a systematic way. After this initial analysis with the assistance of Atlas, themes were selected based on the extent to which they were relevant to the research goal of understanding how teachers' education can be used to create social change. This was another area in which the researcher's subjectivity and judgement affected the content and direction of the research.

\subsection{Feminist Writing Style}

Margalit Yosefon (2001) discusses the significance of choosing a style of writing within the context of feminist research. She notes that whilst a traditional, 'scientific' style may lend itself more to the academic community and to publication, it can also alienate the community whose contributions were vital to the research process and limit the audience that will benefit from the research.

This research, which seeks to implement the principles of critical feminist pedagogy, uses feminist writing style. This includes writing in a clear understandable style, as well as presenting research findings in a practical way for the academic community and early childhood teachers who contributed to this research. Choosing this writing style limits the extent to which research can be presented in a traditional academic format. The research methodology, which locates all theoretical insights in the field in which they were created and use personal narratives as the bridge between theoretical insights and practice, does not lend itself to creating a separation between the results and the discussion of their significance. Instead, both the research material and discussion of its consequence and significance will be discussed in the following section.

\section{Results}

\subsection{Feminist Consciousness Raising}

Sue Middleton, a feminist education researcher from New Zealand describes how she chose a career in teaching because she wanted to live in the city. It was her dream to attend university and she considered studying nursing or teaching, which the only two possibilities available to her as a woman at that time (Middleton, 1993). Gender also influenced my choice of a career in teaching. I chose teaching at a young age because there were many evening classes in teaching programs and I had to work during the day to support my husband who was studying architecture - a prestigious, masculine profession. I was not aware at the time, like many of my current students, that by choosing to become an early childhood teacher I was opting for a low-status, feminine profession that suffers from poor social image and low income. At the time, I received a lot of reinforcement for my choice from my parents-in-law and my mother who was also a kindergarten teacher.

As part of raising feminist consciousness, my students and I discuss the personal and political factors that contributed to their choice of a teaching career in a way that investigates painful issues of gendered power relations, control and the repression of both women and men. We discuss how such important choices are influenced by both social factors and individual character and seek to clarify the relationship between the personal and the political in individual students' lives.

In the 1970s, I went to study in the United States, where I was exposed to feminist thinking. I returned to Israel with a Master's Degree in Early Childhood Education and received a position as the supervisor of a kindergarten. My partner's family did not approve, they saw my increased responsibilities at work as detrimental to my "naturally" assigned role in the family. I was expected to wait at home for my husband to return from work and my children to arrive home from school with dinner on the table and a clean home. 
Like many of my current students, as a beginning teacher, I saw my role in the classroom as an extension of my role as a mother and this was reinforced by the messages I received from my family. In his study of student teachers' perceptions of teaching, Gustavo Fischman found that many female students view teaching as an extension of motherhood (Fischman, 2000). This is also reflected in the Hebrew language where homeroom and the homeroom teacher are referred to as a "mother teacher" and "mother class." This can be seen as a reflection of an ideology that views teaching as a second motherhood, thus demeaning the work of professional teachers and continuing social stereotypes and prejudices that continue to code teaching as specifically feminine work.

Paulo Freire (1996) argues that the identification of teachers as "aunties" undermines the professional nature of a teacher's responsibilities. The subtext of viewing teachers as good mothers or aunties is that like good mothers, teachers should not strike for better pay, fight for their rights or challenge social conventions. Feminist critical pedagogy seeks to recognize how this attitude affects the teaching profession and to generate critical consciousness among student teachers.

The early childhood program in our college requires intensive investment from students in time, energy and intellect. By the end of the first year of studies, students often realize that teaching demands long working hours, complex skills and substantial responsibilities that do not fit their image of a family-friendly, low-responsibility job. In my classes, we analyze the choice of teaching as a career and seek to raise awareness about the complex social factors that contributed to this decision, often inspiring thoughtful reflection about the kind of education received by women.

I teach an intensive unit on feminist theory and history. My students often express shock that they have not previously been exposed to these ideas. I ask them to write an essay that connects this new knowledge to their personal lives. We analyze their experiences as student teachers from a gender perspective and they begin to identify connections between their identities as young women and the biased education that young boys and girls receive. We discuss the possibility of educating children differently, despite the gendered socialization that we have received.

We discuss society's attitudes towards teachers both on general and personal levels through a feminist critical lens, applying the different feminist theories we have studied. We discuss how society places a low value on teaching and how public opinion tends to blame teachers for the low level of education, viewing individual teachers as ignorant, unintelligent and lacking basic knowledge. We discuss the real conditions of teachers, such as the difficult working conditions, overcrowded classes and low wages. We discuss unrealistic instructions given to teachers by their supervisors, the rigid curricula and the endless bureaucracy and explore how teachers are trapped in a situation of unrealistic expectations and limited autonomy (Smith, 1995). We often begin with person experiences as described by the students and continue with the examination of the broader social phenomena that underlie these challenges.

\subsection{Cooperative Syllabus Building}

For many years I have been guiding my students to create dialogue with the children they teach about their interests and to use these to decide the curriculum. Children always choose subjects that stimulate their imagination like dinosaurs, witches, cooking and space. My students develop these themes into wonderful learning experiences. Reflecting on my own work, I have come to realize that I should apply the same approach to my own students. If five year old children can choose the contents of their learning, so should students who are soon to become teachers.

I started to invite my students to be my partners in building their own curriculum and in facilitating the sessions. I shared my thoughts with them about their role determining the learning process and we agreed to have a flexible approach to the lesson content. Prior to each lesson, I share my plans with the students allowing them time to raise issues of concern and interest. Many sessions that opened this way led us to studying totally different themes and subjects that what was planned, yet these topics proved meaningful to the students and met their needs.

When I ask students to take an active role in planning the syllabus, they often react with confusion and dismay. They claim they don't yet know enough and that I am the one who holds the knowledge and should therefore decide for myself. We then discuss other situations with which students are more familiar, like choosing a profession, a school or a partner. We then analyze our support systems and the logic used to make these decisions. The students suggest examples from their lives and we use them as case studies. This helps us see that similar principles of decision-making continue to resurface and they apply these to the process of developing our curriculum. Once engaged in the process, students gather information from other students, colleges and programs and talk with teachers who they appreciate and begin to define what is important for them to learn.

Looking for reinforcement for my approach within the academic literature, I discovered the work of Ira Shor who applied a similar method at the University of Long Island (Shor, 1992, 1996). Shor's description of the process he leads his students through inspired and encouraged my own practice. Later, in 2001, I had the opportunity to visit some of his classes and observing him teaching has empowered me both intellectually and emotionally. I believe that reflection on 
the development of my own pedagogy has the potential to empower my students in their teaching careers. Involving students in planning the training that they will participate in stems from my desire to have them implement the same theory in their work with children. The goal of empowering them to influence and direct their learning leads them to take responsibility for their learning, creating feelings of satisfaction and fulfilment.

The result of this process of collaboration is that the curriculum contains material that seems valuable to me, primarily focusing on the divisions in Israeli society between the rich and poor, Jews and Arabs, Sephardic and Ashkenazi Jews and discrimination against Ethiopian migrants, disabled people and more. We also discuss critical education theory and I provide practical workshops as requested by students, demonstrating various books, games and creative activities. We discuss issues such as listening, working with parents and the development of identity. We thus establish balance between theory and practice guided by the students own needs.

\subsection{Power Relations and Division of Power}

Co-constructing the syllabus made me reflect on the power divisions between teachers and students and its implications. Following Jennifer Gore (1992) I began to doubt my ability to empower others. Gore criticizes the concept of empowerment and claims that the assumption behind the idea of empowerment is that one has power and has the ability to endow it to others. Gore criticizes Giroux and McLaren who emphasize division of power and critiques their approach to power that suggests power is possessed by some and can be given to others. According to Gore, both Giroux and McLaren view power as a zero-sum game, as a merchandise that passes from one person to another and therefore, giving of power to others involves the giver "losing" some of his power (Gore, 1992). I began to consider Gore's critique when I was in the process of collaboratively building curricula with my students and asking myself if this reduced my power as a teacher. I began to consider if it might be possible that rather than me losing my power, we together increased our powers?

Foucault (1980) sees power as operating through dynamic action, rather than existing as an asset that is held by some. He describes power moving freely within a network of people. His approach also raises question regarding the possibility of empowering others. According to Foucault, empowering means using our power to help others discover their ability to use their own powers. This perception does not see power as existing or not existing in certain people, but instead considers that power always exists in potential.

My understanding of empowerment draws on the Israeli reality in which masculinity is demarcated by military power. Gender division is situated in relation to the use of violence and power. Boys and men are taught to apply power and violence to "protect" women and children over whom power is applied. In Israeli culture, this often results in the creation of a view of power as a dichotomy between the those with power and the powerless, the strong and the weak, those who will live and those who will die. This polarization contributes to the continued exclusion of women and minorities from the exercise of power (Gor and Mazali, 2001).

Children also acquire polarized attitudes towards power. From a young age, we teach children to think in binary terms: black, white, good and bad, boys and girls. Memorization strategies train children to think in dichotomies that tend towards gendered and militarized modes of thinking. These false dichotomies create the illusion of differences where they don't exist. Critical reflection of the power division in Israeli society should form the basis for critical analysis of the power relations that are already manifested in kindergarten. In Israeli society, dichotomized social thinking leads to a dichotomous division of power which is accepted and taken for granted, for example, children are often divided into groups of high- and low- achievers.

My students tend to see an absolute power division between teachers and students on all levels, viewing teachers as powerful and students as powerless. I discuss with them questions of power in different contexts, such as power over the curriculum, grades, student's assignments etc. I also try to channel discussion to the examination of power as an energy that floats between us and can be transformed, rather than as a property that I, the lecturer, was given by the institution that hired me.

I try to facilitate processes in which both my power as a teacher and my student's power increases together, avoiding competition, negotiation or attempts to "share" power. We try to create and strengthen power by encouraging in-depth learning that is relevant to preparing the students to become teachers. Sharing decision-making about our curriculum, allowing students to choose topics for study that interest them and giving students responsibility for presenting some material in class results in students enthusiastically studying subjects that engage them, simultaneously enriching my experience as a teacher and creating strong relationships. This allows the curriculum to be responsive to the real needs of the students and the dilemmas they face in their practicum, as opposed to my pre-planned program. it also means that students can implement what they have gained from our discussions in their practicum, restructuring knowledge and power in their own classrooms. 
A view of empowerment as the use of power to help others realise and use their own powers lends itself to practice in hands-on, first-hand learning. Managing a lesson for a kindergarten, determining the contents and activities and implementing the educational theories learned in their training verifies the student teachers' capacity to influence their students and create change thus activating their dormant power that may have been suppressed in other educational frameworks.

Discussing power relations and empowering processes can be confusing and lead to conflict driven by values, differences and contradicting needs. My style of classroom management sometimes gives rise to anxieties and objections from students who are not used to it. In one class, a few students became upset at the feminist content I raised and at my feminist views. They saw collaboration in determining subject matter as a total transfer of power from me to them (thus viewing power as a limited commodity). They expected me to solely determine the curriculum and for me to adjust completely to their wishes and expectations, even though they were only a small part of the whole group. When I refused to completely accede to the wishes of this group this provoked tension and anger in the classroom. Ira Shor claims that it is impossible to prevent conflict and in such a circumstance it is often difficult to resolve a conflict (Shor, 1992, 24).

\subsection{Participant Flow}

For experimental and quasi-experimental designs, there must be a description of the flow of participants (human, animal, or units such as classrooms or hospital wards) through the study. Present the total number of units recruited into the study and the number of participants assigned to each group. Provide the number of participants who did not complete the experiment or crossed over to other conditions and explain why. Note the number of participants used in the primary analyses. (This number might differ from the number who completed the study because participants might not show up for or complete the final measurement.)

\subsection{Transformation of One's Point of View}

Critical feminist pedagogy sensitizes students to the existence of many perspectives on different issues. Feminist theory emphasizes themes that give a voice to marginalized groups. One example of this is Carol Gilligan's (1985) explanation of the gap in results achieved by boys and girls in Kohlberg's test of moral development. Kohlberg argued that boys reach a higher level of moral development as measured by his scale. Gilligan suggests that the moral perception of girls develops differently and that girls and women think about moral decisions in terms of networks, relationships and caring for family members and friends, while boys think in terms of concepts of absolute justice (Gilligan, 1985).

Often my students go through a process of conscious transformation in order to be able to speak on the level of and understand the children with whom they work in their practicum. This can be a long and painful process and I put a lot of effort into encouraging my students to consider other perspectives on various issues and experiment with viewpoints with which they are unfamiliar.

Simulation exercises such as viewing the world from the perspective of a three year old child demonstrate the importance of acknowledging how viewpoints fluctuate from person to person and how the experience of reality is bound to age, personality and social context. To create awareness in students about the impact of viewpoint on our perception of reality, I use video art pieces such as Peter Campus' Three Transitions (1973) or Tirza Even's Pan (1995) to show how these artists observe themselves as artists, reflecting on the process by which they perceive reality.

Documentaries made by marginalized groups about themselves also help to change how we perceive them and allow us to critically examine how outsiders construct their gaze on that particular group. "When Billy Broke his Head" (Golfus and Simpson, 1995) is a documentary about the struggle of people with disabilities to gain their rights in the United States. Billy Golfus, the main character in the documentary, gives us access to the voices of people who live with severe disabilities and who experience unequal treatment and stereotypical attitudes in society. Without mentioning the term ableism, Golfus confronts us with our own prejudice against people with disabilities and shakes our stereotypes.

I present this film alongside discussion, personal narratives and storytelling as part of an ongoing dialogue to contemplate and rethink our viewpoints. We thus create a discourse that allows different social groups to express their voices in class and student teachers develop an understanding and openness to look at the world through the eyes of others.

\subsection{Practicum in Populations with Low Resources}

I send my students to practice teaching in neighborhoods with a low socio-economic status, where they teach children who live in poverty and belong to minority groups. This further helps them break their stereotypes and prejudices.

Students of education studies are required to undertake a practicum in an educational institution assigned to them by the college as part of their teaching certificate. Many students report that this practicum is the most meaningful aspect of 
their learning and often their experiences in the practicum are more influential in shaping their worldview than any other part of their preparation process. I believe that choosing the place for the practicum is therefore very meaningful for the teachers' training.

By spending their practicum with children who live in poverty, the students begin to dismantle their acquired biases and judgements and build a more complex perception of society. The kindergarten classes and nursery schools where they practice incorporate mixed Jewish and Arab classes, some include children with learning disabilities, deaf children and those from migrant and refugee homes. The diversity of classes in which the students practice is reflected in our discussions in the college. Students share experiences of events and dilemmas encountered on practicum and their examples are rich and meaningful. The students usually experience a profound transformation during their practicum that shapes their attitudes towards education. They expand their horizons and come to see that social change through education can be possible. They also realize what a major influence they have on children's lives and comprehend the connection between good teaching and social consciousness.

At times students have raised objections to their placements. When the first Intifada broke out, a few students did not want to travel by buses for fears of terrorist attacks. In other circumstances, reactions such as "I have never been to this neighborhood", "I am afraid to go there", "I don't want to work with Arabs, or children of migrant workers" are heard. I try to listen to their fears and deal with their anger. I give them a choice between the different marginalized groups and I try to positively respond to their preferences. Nonetheless, I do not facilitate a practicum in high socio-economic neighborhoods. As time goes by, even students who objected at first learn to accept my choice of placement and understand its value. They learn to love their pupils and realize that children are wonderful everywhere. They learn to identify and modify their prejudices and develop an attitude of equality towards all children, disregarding their origins.

By participating in the practicum in classes with children from marginalized groups the students gain of practical teaching experiences and dilemmas, which can then function as examples for our class discussion. Student teachers raise issues of language, discipline, acquisition of concepts and social interaction and I discuss these issues with them when I supervise them in the field. The feedback I provide often touches on issues of social equality.

An example of this can be seen in a discussion that took place in a kindergarten where one of my students was placed. This student claimed that all the children in this kindergarten, including those of Ethiopian descent enjoyed equal educational opportunities. However, when I came to visit this kindergarten, I noticed one of the Ethiopian children, Shmuel, was continuously crying. He complained to the teacher that the children took away his toys when he was asked to share and in the playground he cried because he did not get to go on the see-saw first. My student explained to him that he had to wait in line, but he refused and continued crying. I asked the child who was first in line if he would mind giving his turn to Shmuel and he did easily. Shmuel calmed down and later we discussed the event in class, analyzing the sense of deprivation that Shmuel has accumulated. Later the student teacher found out that the teacher (who was of Yemenite origin) tried to explain the difference of skin color by associating it with chocolate. When I asked my students to ask the Ethiopian community how they felt about the comparison of their skin to chocolate, they discovered that the people they interviewed found this to be insulting and repulsive. The seemingly sweet, positive message that the kindergarten teacher had tried to convey to the children in her "chocolate child" explanation was based on a children's book by the same name (Cohen, 1998) proved distasteful and emotionally loaded to the Ethiopian community. Shmuel at the age of five had already internalized a sense of exclusion, the obligation to wait his turn may have resonated to the negative feelings associated with the chocolate explanation and the cooler of his skin.

Over time, the repeated discussions about the experiences and dilemmas of the students from their practicum with marginalized groups led to a transformation in the way that they looked at these children and their parents. Instead of adopting a judgmental view, the students became more aware of the realities of their pupils and more sensitive to the social contexts from which they came.

There are many examples of these transformative processes. One of my students was placed in a class with Alex, a child of a Russian immigrant family, who often misbehaved and disrupted the activities of other children and the teacher. My students watched the teacher warn him, reprimand him, punish him and apply sanctions. They saw Alex become a scapegoat and develop patterns of entrenched negative behavior. The student teachers tried to apply alternative methods, complimenting him often on positive activities, planned activities that suited his desires, and avoided punishing him. In reaction his behavior improved. These students wrote a paper at the end of the course on the issues of prejudice and discrimination against immigrants from Russia.

In another case the disruptive child was Adam, an Arab child. His name was called over and over again in the classroom with a reprimanding tone. In addition to giving him positive attention, my students focused on reinforcing the richness of his cultural background. They asked his father to write in Arabic all of the children's names. The students also told amusing Arabic folks stories, and celebrated a Muslim holiday in the classroom. These activities drew Adam to the 
center of attention as a source of knowledge. Eventually, he developed a sense of self-worth and gained his friends' appreciation for his uniqueness. His disruptive behavior diminished and disappeared.

\subsection{Analyizing Gender Inequalities}

In our sessions, we also analyze events connected to gender inequality in early childhood classrooms. By studying feminist theory and its application to early childhood education students are exposed to a new way of perceiving their social reality, recognizing the ways they have been oppressed as young women in a patriarchal society and directing a critical gaze towards practices of early childhood education. Together we try to expose sexist messages hidden in the curriculum, in the physical infrastructure of the kindergarten and in the interactions between children.

Often the students are able to identify the different phenomena that mark gender inequality after I have drawn attention to it by asking questions like how much space did the boys and girls take up in the yard and what games are typical to boys and girls. Over time the students develop the capacity to observe independently and to discover overt and hidden manifestations of gender inequality.

An example of an instance where we discussed gender inequality in the context of my students' practical experience took place when one of my first year students found a group of five year old boys whispering and laughing in the toilets. When she approached the boys asked her to take off her underwear. My student froze, not knowing how to react and then she left, shocked and upset. During our class discussion we tried to understand the source of her emotional reaction. We asked her what was brought up for her as a result of this event both in her mind and in the minds of the other female students. We found that many female students had memories they associated with harassment: a stranger pushing himself on a young girl in a bus, a group of young men making comments on a woman's body while she passed by and many more. We then read about sexual harassment and tried to understand feminist theories that view sexual harassment and rape as a mechanism for male control over women. We then discussed the development of perception in five year olds based on their background and environment.

After analyzing the event from the point of view of the children, men and women and girls who have been exposed to sexual teasing, we could understand why our student was unable to react and we tried to offer alternative ways to cope with such events, seeking a reaction based on professionalism that was sensitive to the needs of the children and not based on the sense of victimization and vulnerability that is part of our socialization as women.

In a similar way we tried to dismantle concepts of power and control by observing different relationships between parents and children, teachers and children and men and women. By emphasizing paradigms of power and control, we draw attention to women's ability to deconstruct social phenomena and the social constructedness of power divisions between various groups in society.

The practical experience of working with students from marginalized groups exposes and sensitizes students to the role they play in entrenching existing inequality. We discuss and seek to understand our own capacities as women and men to dominate others and recognize how the dynamic nature of power relations makes it possible for women to be oppressed by men and their social circumstances, but then go on to be oppressive towards their own children. This duality exists in each of us. Teachers, for example, may experience insulting and oppressive social attitudes, but at the same time implement an oppressive system over the children in their care, mocking them and frightening them. Paying attention to the multilayered systems of inequality that create oppression based on gender, ethnicity or class can expose the commonality between different kinds of oppression (bell hooks, 1989, Gor Ziv, 2015).

Critical feminist pedagogy links discrimination based on race, class, gender, age (ageism) or physical disability (ableism), since all these forms of oppression are based on mechanisms of exclusion. Becoming aware of the ideological links between various forms of discrimination that are targeted against different groups is essential for liberatory education. As long as women's oppression continues it will be hard to achieve ethnic, class or racial equality. By identifying different kinds of oppression in education students develop self-awareness and begin to recognize the common points in various forms of oppression. This often later crystallizes into an independent social outlook.

In my feminist outlook I greatly value the synergy between practice and theory. However, the feminist theory that has flourished in universities was created by women of the middle-upper class and sometimes fails to reach the field of early childhood education. bell hooks (1989) claims that feminist theory can become another instance of academic elitism and emphasizes the need for the creation of an accessible feminist theory that directly stimulate activism for change. She therefore sought to write in a way that would be accessible for all social classes.

Sending my students to a practicum in working-class neighborhoods enabled them to combine theory and practice. This approach is reminiscent of the Whole Language Theory that discusses how the acquisition of a second language needs to be similar to the development of one's first language. Similarly, the practicum with disadvantaged children is an 
organic natural learning experience in which the students' work with the children is the motivation for learning theories that explain the concrete questions that they have encountered.

\subsection{Personal Narratives and Critical Observation}

Working with marginalized groups results in the students" understanding of their own silenced voices. The term "voice" as an embodiment of a unique expression of an individual or group is an important concept in feminist thought. The process of creating a critical consciousness encompasses awareness of the need for self-expression and giving "voice" to various aspects of our lives, particularly the experiences of marginalized people (Field, Belenky et al, 1986, 13). Many of my students experienced a culture of silencing in their high schools and later in their army service. They prefer not to deviate from what is expected of them. Finding their own voice, the courage to doubt and the ability to express their own opinion are essential components in the struggle for their own liberation and the liberation of the groups to which they belong. In order to strengthen personal voice, we engage in writing personal narratives from childhood that relate to issues of education and equality.

One of my students wrote:

"It all started in fifth grade, when I played tennis. I was a girl from Neve Sharet in Tel Aviv. Everyone who heard where I came from raised an eyebrow. I did not pay much attention to it at first. I had lived in my own bubble until then where everything was nice and beautiful. The fifth grade was the first time I got out (of my neighborhood) and met with the children of Ramat Hasharon, and that was a painful change. I remained lonely, no friends. As opposed to the Ramat Hasharon kids: I was a Tel Avivian girl from a "poverty stricken neighborhood" (that was how they referred to me) versus the children from the fancy groomed houses. Suddenly I was not Yamit anymore, a sweet, funny sociable girl. I was Yamit the poor girl. The kids of Ramat Hasharon were not interested in getting to know the real Yamit, the real person. It hurt. I felt alienated, not good enough for the people of high status. This feeling stayed with me for years later."

It is possible to view in this writing how Yamit connects the suffering she endured in the fifth grade to her social class. Her reflective observation draws on the theory she acquired later in life which allowed her to process these painful memories. This demonstrates how theory can give relevance and meaning to experiences by placing them within a larger context.

Paulo Freire writes in Letters to Christina (Freire, 1996) that for him returning to his childhood memories as an adult was necessary as an an act of curiosity, allowing him to become more aware of the social circumstances in which he grew up and also the impact of these experience on his adult life. The process of re-examining childhood memories as an educated adult creates continuity between our child and adult selves.

"The children I met in junior high school wore designers' cloths," Yamit continued, "I belonged to the unpopular group of kids, the poor kids who were not up to date with the new fashions or the new slang of the day. We were the 'others'. They wouldn't talk to me or get close to me, as if I had leprosy. I came from a neighborhood with a high crime rate, so they assumed I was a criminal. I felt lonely...no one to talk to but my teacher. But she said we kids have to work it out among ourselves; that goal of a school is studying rather than social gathering. My illusion to receive help was shuttered."

With the perspective she now has, Yamit was able to critically observe her teacher's role in maintaining the social stratification. She quoted her teacher's reasoning with pain and cynicism. As a student she dreams of becoming a teacher who is able to be involved in all aspects of her students' lives and approaches teaching holistically. She understands that by being sensitive to children's social attitudes and the effects of class stratification she may be able to create change.

Paulo Freire explains that the suffering of our child selves can lead to the activism of our adult selves. He rejects psychoanalytic approaches that view involvement in social activism as a craving for love. "I was never alone," he claims "and I have never doubted my family's love to me". (ibid. 14-15). Freire claims that his resistance to class structure should be viewed in the context he grew up in and the hunger he experienced in his childhood. "I felt defeated by hunger while doing homework; I did not need research to probe the connection between malnutrition and learning difficulties. I had a primordial experience of this connection" (ibid. 14-15).

By reading Freire's childhood experiences with my students and discussing their own childhood experiences we begin to explore a wider range of social perspectives. As mature adults they are able to interpret the social reality in which they grew up and reject explanations that do not satisfy them or caused them pain as children. The students often experience similar reactions to those of Freire. By writing her personal narrative, Yamit reclaimed her story and created solidarity with students who had had similar experiences, such as another student who recalled how in class they had sat in different rows in the classroom, divided according to the neighborhoods they came from: two rows for the children 
who lived on the western side of the city's main road, and two rows for the children who lived on the eastern side of the main road. This division reflected the demographic divide along this major road between Ashkenazi Jews and Sephardic/Mizrachi Jews. These kinds of personal accounts drew attention to stories that were not heard in the cultural hegemony that only tells stories that further its aims (Giroux, 1998).

Another student wrote:

"I felt suffocated in that damned, judgmental system of my settlement. I swore I would return only after that feeling has disappeared and I have a stronger position against those opinions that have labeled me and others like me. For example in the first grade, Ronen, Oded and Shabi were taken out of class for lessons given in a small groups for slow learners. They were oriental kids who came from a nearby village. The system labeled them as slow learners before the school year has even started. I don't believe all three had the same learning disabilities what they had in common was the color of their skin and oriental origin. At that time, exams for learning disabilities were not used in Israel. The three pupils were marked by the system that had adopted a colonialist cultural attitude. Later I met one of these three pupils Oded, again in high school at a high achievement class where he succeeded in spite of the system that had labeled him as a slow learner in an early age.

The school's staff was all women except for the male principal. All the teachers came from the well-established nearby villages. I knew all of them not just from the school's activities, but from community events. I also knew their children who were more or less my age. They somehow marked the boys from the low class village as in needed for special instruction, as low achievers who had to "be strengthened". They were separated from us, as not to disrupt the "high level" Ashkenazi children."

This account shows my student translating the sense of injustice that she felt as a child into the theoretical language she has acquired as an adult, thus creating a connection between theory, practice and personal voice that allows for the development of new social insights and meaningful engagement with past experiences.

\subsection{Language}

Writing reflective journals, personal narratives and academic papers serves as means of creating meaningful and relevant knowledge. Sharing these writings within the group often leads students to the recognition of the connections between these experiences and broader theoretical and social themes. This helps creates social consciousness and a sensitivity to the "other." Language has a significant role in the production of meaning by allowing us to conceptualize our experiences. It provides an interpretive framework of codes and cognitive schema that allow us to mediate our experience and understand our reality (McLaren, 1995).

The reflection that students undertake in their personal narratives and experiences is crucial in the struggle to create social consciousness but it must be combined with other efforts to view the Other as a subject and not an object. While the students voices are meaningful, there is also a need to strengthen their voices and consider them through theorization and knowledge generated through other channels.

We think and speak about our experiences through language that shapes how we understand causation. A student that witnesses a teacher shouting at a student and is shocked by this can explain this though the language and discourses available to her. She could interpret the event as an example of the oppression of children or as an understandable reaction to the difficult working conditions of teachers. The choice of explanatory discourse will be reflected in her reaction to the situation and in her future practice as a teacher.

The language of teaching functions as a limiting text that formats the way teachers and children understand schooling. The language we use therefore determines, at least partially, the way we understand our experiences (McLaren and Da Silva, 1993). In their training, the students are exposed to the use of hegemonic language and discourse. The hegemonic language in education is centered on labeling, classifying, diagnosing and tracking students. In the professional literature and in their practicum, students are exposed to a language that labels children based on their social class, ethnicity and gender whether consciously or not. This language, based on psychological theory, represents a worldview that does not recognize oppression based on gender, social class and ethnicity and instead believes in inherent differences between children in their learning capacities, their pace and their learning style.

The consequences of this discourse include the creation of stratified classes from the first grade in elementary school, separating "capable" students from "incapable" students. These labels become definitive for children. Critical pedagogy encourages us to create a different language that is focused on possibilities for learning rather than deficiencies in learning and draws critical attention to the educational practices that create inequalities amongst children.

Subjectivity is a function of language. At the same time as we use language to conceptualize ideas, the constructs of language shape our understandings. According to Bakhtin (2008) the main function of language is not to represent objects in the world, but to give an external expression to the inner structure of established thought in a way that 
preserves the existing social order. Hence the discourse of teaching can be seen as a language composed of specific vocabulary, narratives and ideas that are accepted as legitimate. Often this language is drawn from administrative management in the corporate world, which does not reflect the complexity of social life.

Students are exposed to various statements about children they teach during their practicum, such as "nothing good will come from this kid," "what can you expect, his father is a junkie" or "it's a waste of time, the kid belongs in special education." Even when voiced out of compassion, these statements label children according to a language that stratifies them based on perceived deficiencies. In order to offer alternative explanations of children's behavior, we must seek out an alternative language.

Yuval was a first grader who was forced to repeat because of poor achievements. When the school year started he knew already all words taught in spelling since it was his second year in first grade and he refused to fill the worksheets the teacher gave him. The teacher reprimanded him and her explanation of the situation assumed that Yuval was a "problem child" with many difficulties at home, who better fit special education because of his disruptive behavior.

In the current school system and within the existing educational discourse, this explanation sounds reasonable. In the discourse and language of critical pedagogy, where the pedagogy itself is the subject of criticism and not the child we can seek to explain Yuval's behavior based on the assignment he was given, not in his deficiencies. When we strive to apply a language of possibilities, the main questions asked would be what kind of educational situation was needed for Yuval to succeed and how can he be assisted to reconnect to his talents and capabilities in order to study.

\subsection{Resistance}

Ira Shor states that creating democratic dialogue in classrooms is often met with resistance from students, teachers, parents, authorities and school management. Students who come from an educational background based on the banking approach to learning internalize values and behaviors that impair their critical thinking. Education often directs children to the memorization of material, leading them to develop an alienated and anti-intellectual approach to social problems and to become uncritical citizens who blame themselves for their failures and are thus easier to control (Shor, 1993).

In a traditional classroom, students are required to memorize material that is dictated by the teacher. In a classroom where students are expected to provide their own motivation and self-discipline and work to create new knowledge, some students interpret this change in learning paradigm as an excuse for superficial learning, lateness and absenteeism. In a classroom run by principles of critical feminist pedagogy, these behaviors become topics for discussion, rather than opportunities for coercion.

Some students prefer to reject the invitation to doubt and ask questions about the worldviews they have internalized, instead interpreting the invitation to question official knowledge and mainstream political discourse as the erosion of boundaries and a lack of authority. One instance of this took place when I gave a student who did not invest effort in her studies with a low but passing grade and added a letter that conditioned her continued studies on a demand for more rigorous effort on her part. The other students in the class united against me to demand that I change her grade and cancel the condition I had put on her continuation. They used power to determine the agenda in a way that seemed similar to what we had been practicing all year and they tried to force me to change her grade. My refusal to cooperate caused their anger. In later reflection I saw this event as positive as it demonstrated the change in perspective with regards to power, even if in this instance they used power in a negative confrontational way that contradicted other values (such as the obligation for discretion in students' evaluation). This event sharply uncovered students potential to resist the teacher's authority to evaluate work, which is usually unquestioned in a traditional classroom.

Critical pedagogy can be confrontational and learning through these methods is not always pleasant and risk free. Students may express resistance in class though arguing, aggression and intellectual and emotional debating. Their discomfort may also be voiced indirectly during breaks and interactions with other students. The transformation from traditional and authoritarian notions of the role of the teacher to democratic and critical ones is a long and challenging process that goes against twelve years of schooling that conditions students to see education as the transfer of information from a full vessel (the teacher) to an empty one (the student) (Friere, 1981).

Any group learning process includes resistance. Critical pedagogy may create more resistance because it deals with issues of equality and inequality and touches on painful and sensitive issues for each student. Resistance itself, as much as issues of the personal connection students have to issues of inequality, has the potential to become the subject of research, reflection, questioning and debate.

The exposure to issues of inequality and social injustice often upsets student's naive and optimistic perception of the world. An example of this was seen in a group of students who complained that I treat students from marginalized groups preferentially. We raised these issues for discussion in class and the conversation led to recognition of their 
feelings as well as the social context in which the complaints were raised. The undermining of familiar social structures when discussing themes of inequality might explain my students' reaction.

Resistance appears in many different forms and is not unique to critical pedagogy. It characterizes any process of learning and change. Resistance occurs in children and adults as a reaction to injustice and discrimination. We all recognize a typical response of resistance to narratives that label children from low socio-economic backgrounds, in which children say "my teacher told me I can't, I'll show her she is wrong." This kind of resistance can create the desire to excel and prove oneself.

Less positive types of resistance to oppression and inequality can be observed in children's violent behaviors, directed towards other children and sometimes towards teachers and property. Herbert Kohl (1994) writes about his resistance to learn Yiddish. He describes resistance and refusal to learn as healthy, reasonable and intelligent responses to the brutality and coercion directed against children within the education system. Kohl distinguishes between the failure to learn and the refusal to learn and he describes children from low socioeconomic status and excluded communities as using not-learning as a form of resistance, which is in many situations a healthy, positive act (Kohl, 1994). In matriculation projects with disenfranchised youth that are based on principles of critical pedagogy the teachers try to create ambition to pass the test as an act of political resistance to the labeling the students have experienced.

Sonia Nieto (1999) researches the tragic correlation between the "pressure to succeed" experienced by children in school and the demand for children to abandon their family's culture and values. She shows how Black children in the United States who rejected their family's values and adopted a race-less identity had a better probability of success. This erasure of identity comes at the price of alienation from family and the experience of rootlessness. In her article "You're so pretty you don't look Moroccan" Henriette Dahan Kalev writes about the heavy price she had to pay in order to integrate and succeed in mainstream Israeli society where the dominant culture is Ashkenazi (Dahan Kalev, 2001).

bell hooks uses the term "resistance" to characterize the behavior of students who refuse to accept discrimination against them and conform to the hegemonic agenda that is taught (hooks, 1989). She sees the term "resistance" as challenging the status quo of traditional teaching in a way that includes both conscious and unconscious acts of defiance. She describes her experiences as a Black student resisting the concealed and overt racism of white professors.

Rudulfo Chavez Chavez coins a new term to distinguish different types of resistance (Chavez Chavez and O'Donnell, 1998). He refers to students' resistance to multicultural education as "non-engagement" and suggests that this type of resistance is a means of avoiding dealing with difficult social issues. Robert Bahruth and Stanley Steiner (1998) see the refusal of students coming from the dominant culture to engage with critical pedagogy as a sign of resistance to discovering their voice and thinking critically about the system that privileges them. Bahruth and Steiner try to understand the intimidation and threat these students feel when students from silenced and marginalized groups begin to voice anti-establishment opinions.

Bahruth further discusses his colleague's resistance to his work. He observes that students who have been exposed to critical pedagogy tend to become less conformist and have the vocabulary to criticize traditional teaching, which has led to accusations from his colleagues that he is inciting students against them. I encounter these responses in my career as well. However, teachers who practice feminist pedagogy and teach critical theory often tell me they easily recognize my students in their classes because of their openness, their willingness to develop critical thinking and their interest in topics of justice and equality.

Multicultural education creates change and threatens student's self-perception and worldview. Ira Shor and Paulo Friere (1998) discuss the fear that being involved in critical pedagogy will lead to rejection from the mainstream academy. They both discuss the personal price they have paid for their involvement in critical pedagogy. Ira Shor discusses teachers who were punished, sometimes even losing their jobs, as a result of their radical pedagogy and resistance to school policies.

I see a connection between various types of resistance. Critical feminist pedagogy allows the uncovering and voicing of a broad spectrum of resistances by legitimizing student's voices and allowing students the opportunity to reject what their teachers are offering them. The phenomena of resistance are always similar, even if the reasons for it and the way it is expressed change contextually

\section{Discussion}

This article presented some of the issues that arose in attempting to design a teachers' training program based on critical, feminist pedagogy and evaluated and discussed different tools for raising awareness through teacher's education. These tools included: raising awareness about the students' choice of a highly feminized career path; empowering the students to work collaboratively with the teacher to create their own learning experiences; raising awareness about the 
hierarchical structure of society; creating opportunities to view social disadvantage from different perspectives; using personal narratives as a link between practice and theory and creating awareness of how language creates and shapes our opportunities for expression. Finally, when deploying these tools it was necessary to be aware of possibilities for resistance from the students themselves, many of whom were deeply challenged by radical content of the program.

In addition to the tools discussed in this research, there are other aspects of teachers' training that could be deployed as means for creating social awareness amongst future teachers and providing practical means of educating children for a more just society. These include:

- The deconstruction of narratives transferred through the celebration of and teaching about the Jewish holidays. Jewish holidays celebrated in Israel that have a central role in the early age curriculum, but are usually presented in a highly traditional light. A critical, feminist teachers' training could include a critical, feminist analysis of the alternate messages conveyed in the Jewish holidays. This analysis can create potential for kindergarten teachers to convey ideas of social justice through the teachings of these holidays.

- The analysis of curriculum through critical and conflict theories that emphasize the hegemonic forces that shape the hidden and overt messages in early childhood education. The teacher's college itself could be a subject for such observation.

- Study of the connection between the personal, the group and the political and creating processes in which the group reflects on itself and observes its role in broader social dynamics in a way that allows the classroom to become the subject of research and reflection.

For example, a student wished to share a problem she had with a teacher assistant and she began her description with: "imagine that, a Russian assistant - with this Russian mentality...". A student from Russian descent replied: "it is so difficult for me to hear such biased comments, I feel vulnerable and hurt." On another occasion, students who were born in Israel complained that the Russian students speak Russian between themselves. The Russian students explained they often feel speaking in their mother tongue is necessary in order to explain difficult concepts or to feel more comfortable in the discussion. These two events and others have led us to observe our own classroom through the context of how Israeli society accepts migrants.

The observation was then often turned to the college itself. For example, following a classroom conversation about accessibility rights in the society as a whole, the students suddenly realized that people using wheelchairs cannot study in our college as only very few classrooms are accessible to them. In another occasion, the students researched the socio-economic characteristics of the lecturers at the college.

In this article, I tried to portray some of the aspects of teacher's training when conducted according to the principles of feminist critical pedagogy. I tried to observe the parallel processes that the students and myself, as their teacher, experience. In addition, I tried to illustrate the connections and tensions that exist when working inside an institution whilst remaining critical of the role institutions play in perpetuating inequality.

Critical pedagogy aims to challenging the acceptance of social reality as it is, and encourages the students to become activists in their own work environment and create equality and social justice through education. The main question remains, how can we educate teachers to achieve these goals? I have discussed a few of my own methods, but this discussion requires further elaboration, reflection and experiences.

\section{References}

Anyon, J. (2005). What 'Counts' as Educational Policy? Notes toward a New Paradigm. Harvard Educational Review, 75(1), 65-88. http://dx.doi.org/10.17763/haer.75.1.g1q5k721220ku176

Bachtein, M. (2008). Late writings: philosophy, language, culture. Translated by Sergei Sendler, tel Aviv, Restling. (Hebrew)

Bahruth, R. E., \& Steiner, S. F. (1998). Upstream in the mainstream: Pedagogy against the current. Rudolfo Cahvez Chavez \& James O'Donnell (Eds.), Speaking the unpleasant: The politics of (non) engagement in the multicultural education terrain (127-147). New York: State University of New York Press.

Campus, P. (1973). Three transitions (video). New York.

Chavez, C. R., \& O’Donnell, J. (Eds.). (1998). Speaking the unpleasant, The politics of (non) engagement in the multicultural education terrain. New York: State University of New York Press.

Cohen, H. (1998). A chocolate child, Tel Aviv, Sifriat Hapoalim. (Hebrew)

Dahan, K. H. (2001). You Are So Pretty, You Don’t Look Moroccan. Israeli Studies, 6, 1-14. (Reprinted, 
in Ed. Ephraim Nimni. 2003, 168-181. The Challenge of Post Zionism London: Zed Press. Also reprinted in Eds. Michal Zelermayer and Pnina Peri, Teachers in Israel: A Feminist Perspective, 2002, 174-186, Tel Aviv: Kav Adom. (Hebrew).

Dascal, M. (2003). Interpretation and Understanding, J. Benjamins Pub. Co. Amsterdam, Co.

De Beauvoir, S. (2001). The second sex, translated by Sharon Preminger, Tel Aviv, Babel.

Ellsworth, E. (1989). Why doesn't it feel empowering? Working through the repressive myths of critical pedagogy. Harvard Educational Review, 59(3), 297-324. http://dx.doi.org/10.17763/haer.59.3.058342114k266250

Even, T. (1995). Pan (video). New York.

Field, B. M., McVicker, C. B., Rule, G. N., \& Mattuck, T. J. (1986). Women's way of knowing: The developoment of self, voice and mind. New York: Basic Books.

Fine, M., \& Torre, M. (2006.). Intimate details: Participatory Action Research in Prison. Action Research, Sage Publications, 4(3), 253-269.

Fischman, G. (2000). Imagining teachers: Rethinking gender dynamics in teacher education. Lanham, MD: Rowman \& Littlefield Publishers.

Foucault, M. (1980). Power/Knowledge: Selected interviews and other writings, 1972-1977. New York: Pantheon Books.

Freire, P. (1993). Pedagogy of the Oppressed, , New York, Continuum

Freire, P. (1996). Letters to Cristina: Reflections on my life and work. New York: Routledge.

Gilligan, C. (1985). In a Different Voice: Psychological Theory and Women's Development, Harvard University Press.

Giroux, H. (1988). Schooling and the struggle for public life: Critical pedagogy in the modern age. Minneapolis, MN: University of Minnesota Press.

Givton, D. (2001) Grounded Theory: Meaning of data analisys process and theory building in qualitative researcc, in in Naama Sabar, ed. Qualitative Research: Genres and Traditions in Qualitative Research, 195-227, Dvir (Hebrew)

Golfus, B., \& Simpson, D. E. (1995). When Billy broke his head ... and other tales of wonder (movie). Berkeley, CA.

Gor, H., \& Mazali, R. (2001), Man-Woman, War and Peace, Panim, 59-51 ,17(Hebrew).

Gore, J. M. (1992). What we can do for you! What can "we" do for "you"? Struggling over empowerment in critical and feminist pedagogy. In: Carmen Luke \& Jennifer M. Gore (Eds.), Feminism and Critical Pedagogy New York: Routledge.

Hooks, B. (1989). Talking back: Thinking feminist, thinking black. Boston, MA: South End Press.

Kenway, J., \& Modra, H. (1992). Feminist pedagogy and emancipatory possibilities. In: Carmen Luke \& Jennifer M. Gore (Eds.), Feminism and Critical Pedagogy (138-166). New York: Routledge.

Kohl, H. R. (1994). I won't learn from you": And other thoughts on creative maladjustment. New York: The New Press.

Kohn, C. (1989). Sex and Death in the Rational World of Defense Intellectuals, in Feminist Theory in Practice and Process, Micheline R. Malson ed., University of Chicago Press, Chicago.

Lather, P. (1988). Feminist Perspectives on Empowering Research Methodologies. Women's Studies International Forum, 56(3), 257-277. http://dx.doi.org/10.1016/0277-5395(88)90110-0

Lieblich, A. (1993). Early and Late in "Rekamot", on biographies, objectivity and women, and Dvora Baron, Alpaiim, 8, 225-239 (Hebrew).

McLaren, P. (1995). Critical pedagogy and predatory culture: Oppositional politics in a postmodern era. London and New York: Routledge.

McLaren, P., \& Tadeu da Silva, T. (1993). Decentering pedagogy: Critical literacy, resistance and the politics of memory. Peter McLaren \& Peter Leonard (Eds.), Paulo Freire: A critical encounter (47-89). New York: Routledge.

Merriam, S. (2002). Qaulitative research in practice: esamples for discussion and analysis, San Francisco California: jossey-Bass.

Middleton, S. (1993). Educating feminists: Life histories and pedagogy. New York: Teachers College Press.

Nieto, S. (1999). The light in their eyes: Creating multicultural learning communities. New York: Teachers College Press. 
Shor, I. (1992). Empowering education: Critical teaching for social change. London and Chicago: University of Chicago Press.

- - (1993). Education is politics. In: Peter McLaren \& Peter Leonard (Eds.), Paulo Freire: A critical encounter. New York: Routledge. http://dx.doi.org/10.4324/9780203420263

- - (1996). When Students have the power: Negotiating authority in a critical pedagogy. Chicago: University of Chicago Press.

Shor, I., \& Freire, P. (1987). A Pedagogy for Liberation, Westport, Connecticut, London, Bergin \& Garvey publishers.

Smith, F. (1995). Between hope and havoc: Essays into human learning and education. Portsmouth, NH: Heinemann

Van Dijk, T. (2003). Critical Discourse Analysis. 352-371. The Handbook of Discourse Analysis, edited by Deborah Schiffrin, Deborah Tannen, and Heidi Ehernberger Hamilton. Maiden, MA; Oxford, UK; Carlton, Victoria Australia: Blackwell. http://www.discourses.org/OldArticles/Critical\%20discourse\%20analysis.pdf

Yosifon, M. (2001). Case Study, in Naama Sabar, ed. Qualitative Research: Genres and Traditions in Qualitative Research, Dvir 257-305(Hebrew).

\section{$(\mathrm{Cc}) \mathrm{BY}$}

This work is licensed under a Creative Commons Attribution 3.0 License. 